\title{
Dalla superficie al volume. Un'indagine grafica del progetto Solidi di Cesare Leonardi
}

Domenico Pastore

Abstract

II progetto Solidi avviato da Cesare Leonardi agli inizi degli anni '80 si fonda su un preciso intento: ricavare dai pannelli utilizzati per le casseforme in cemento armato, una varietà d'oggetti d'arredo domestico, utilizzando interamente la superficie dei pannelli modulari e non impiegando materiale aggiuntivo. Definiti i limiti fisici e le caratteristiche del materiale di base Leonardi prefigura un'articolazione spaziale di pezzi che compongono diversi tipi di sedute o tavolini. In questo studio si vuole fornire un'interpretazione del processo figurativo che articolandosi sul piano, mediante una serie di operazioni di tracciamento e misura, trova il suo esito plastico in una forma volumetrica avente una funzione. Mediante una lettura grafico-analitica della tipologia di poltrone su ruote si cercherà di decodificare le azioni ricorrenti e le modalità di definizione degli elementi che determinano le differenti configurazioni.

Parole chiave

analisi grafica, disegno, design, diagramma, figurazione.

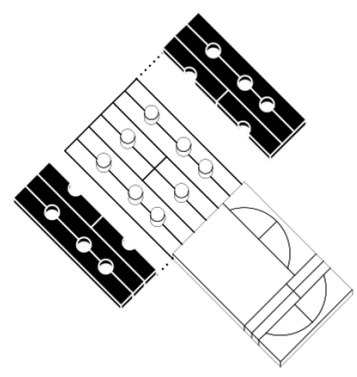

della PRL04
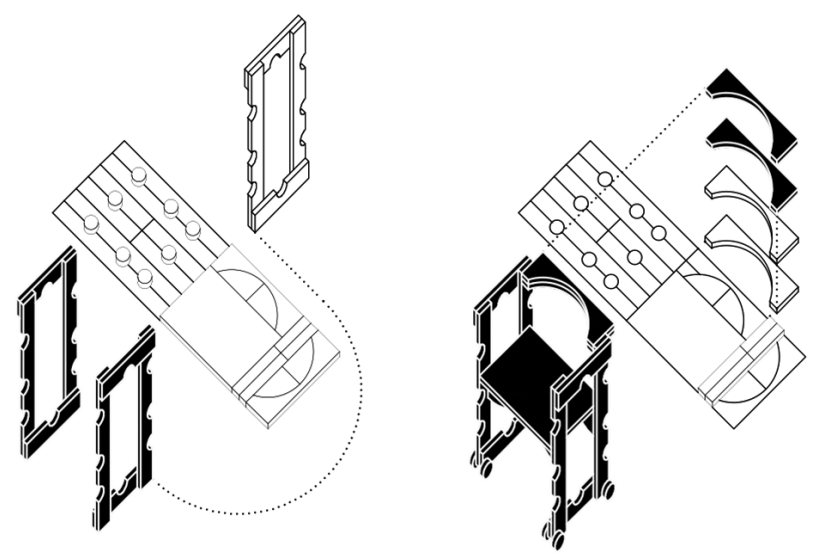


\section{II progetto Solidi di Cesare Leonardi}

Negli anni '80 Cesare Leonardi avvia un progetto di ricerca sul design, fondato sul riutilizzo delle tavole impiegate per le casseforme da cemento armato, nella produzione di oggetti d'arredo. I progetti elaborati dal 1983 al 1993 e documentati nel libro Solidi/Solids seguono tutti lo stesso principio: rispettare "i limiti della tavola di cassero da calcestruzzo da cui sono ricavati senza fare ricorso a materiale aggiuntivo estraneo a quella tavola" [Martinelli 1993, p. 7]. A questo imperativo, incentrato sui limiti fisici e materiali, se ne aggiunge un altro riguardante il destinatario. Tutti gli oggetti sono infatti pensati per soddisfare solamente il designer che li produce e non per un utente estraneo al processo. L'esclusione di un fruitore finale e la coincidenza tra committente e progettista, colloca questa sperimentazione formale all'interno di un ambito prettamente artistico dove l'impulso primitivo dell'uomo di creare oggetti trova la sua profonda soddisfazione nel realizzare cose materiali mediante la manipolazione di una sostanza presente nella realtà, formando un "alcunché di distinto da quanto in precedenza esisteva" [Dorfles 2003, p. 43]. La produzione di un oggetto mediante la metamorfosi di un semilavorato come il pannello di legno predefinito, implica uno sforzo immaginativo più complesso in quanto costringe a pensare l'oggetto non tanto come forma, quanto come processo che ha come esito una configurazione tridimensionale e non la concretizzazione di una raffigurazione nata come "dato immediato" [Anceschi 1992 p. 22]. Per questo, la limitazione a un solo materiale e l'obbligo di sfruttare il massimo della superficie a disposizione per ricavare tutte le parti che compongono il 'Solido', diventano le condizioni necessarie a circoscrivere il campo entro il quale Cesare Leonardi opera per sviluppare una serie di oggetti differenti per forma e funzione (fig. I).

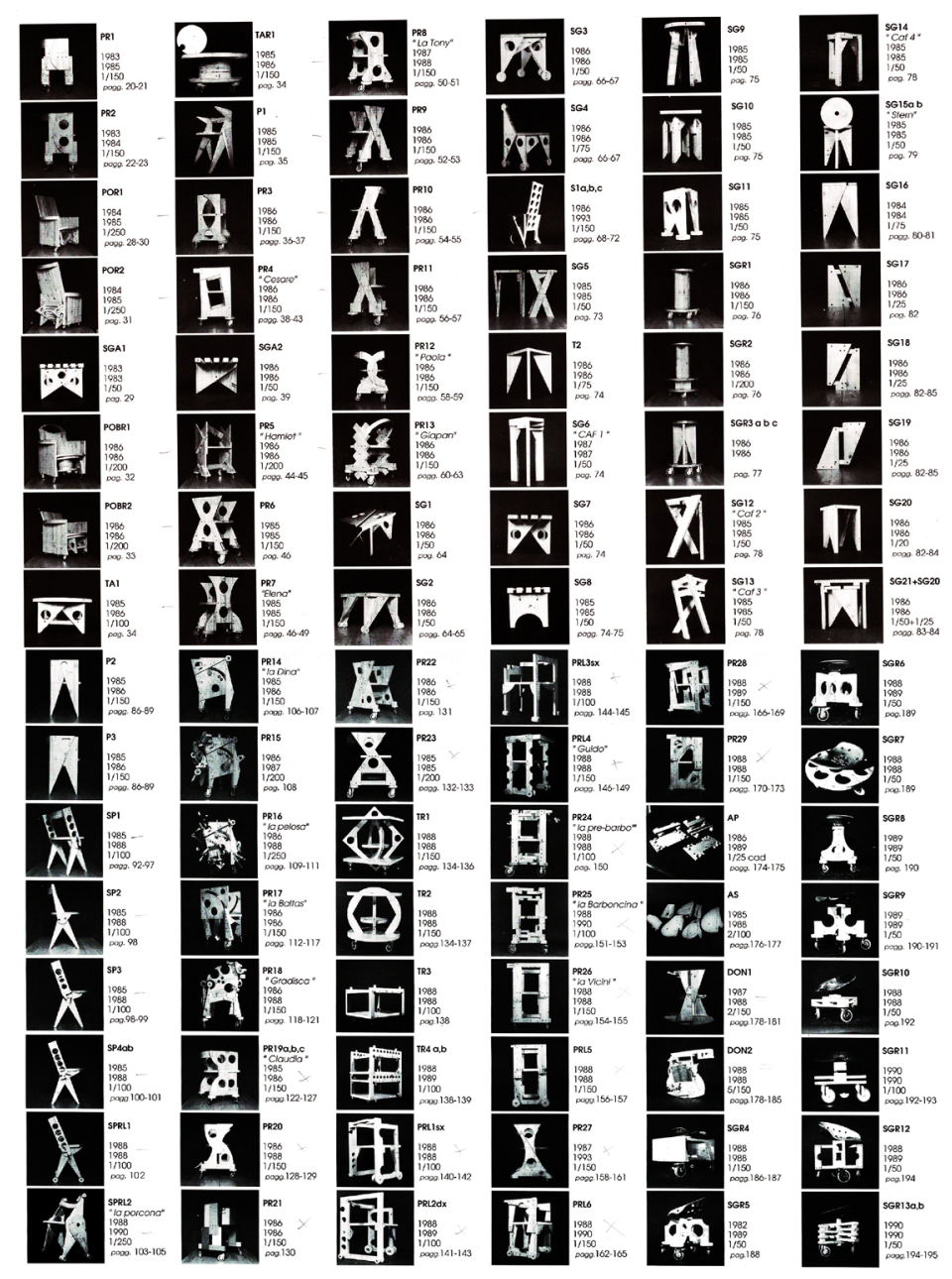


Questo processo creativo, impostato sul rispetto di condizioni prefissate, si potrebbe interpretare come una sperimentazione che tende a verificare i limiti e le potenzialità immaginative dell'uomo-artigiano [Sennet 2019 p. 27] , che si approccia alla costruzione di oggetti seguendo una pratica riflessiva e non un semplice metodo per ottimizzare la costruzione di un prodotto [Leonardi 1993, p. 9].

Ogni 'solido' è già interamente contenuto nel cassero e il compito del designer è quello di estrarlo in modo sempre diverso ogni volta che stabilisce il principio con cui il materiale deve passare da uno spazio bidimensionale a uno tridimensionale. Questo processo non si sviluppa secondo un'unica direzione che dal tracciamento su tavola conduce direttamente alla configurazione finale ma subisce nel corso dell'elaborazione continue trasformazioni che implicano dei cambiamenti in seguito a verifiche costruttive. Ne sono una testimonianza gli schizzi preparatori approntati su carta quadrettata che illustrano schemi di tracciamento su piano e proiezioni ortogonali dell'elevato, accompagnati da rappresentazioni assonometriche d'insieme e di dettaglio che documentano le trasformazioni che ogni progetto subisce quando da rappresentazione bidimensionale assume consistenza nella realtà tridimensionale (fig. 2).

Fig. 2. Schizzi preparatori per il progetto della PRL04 [Martinelli 1999, p. 146.].

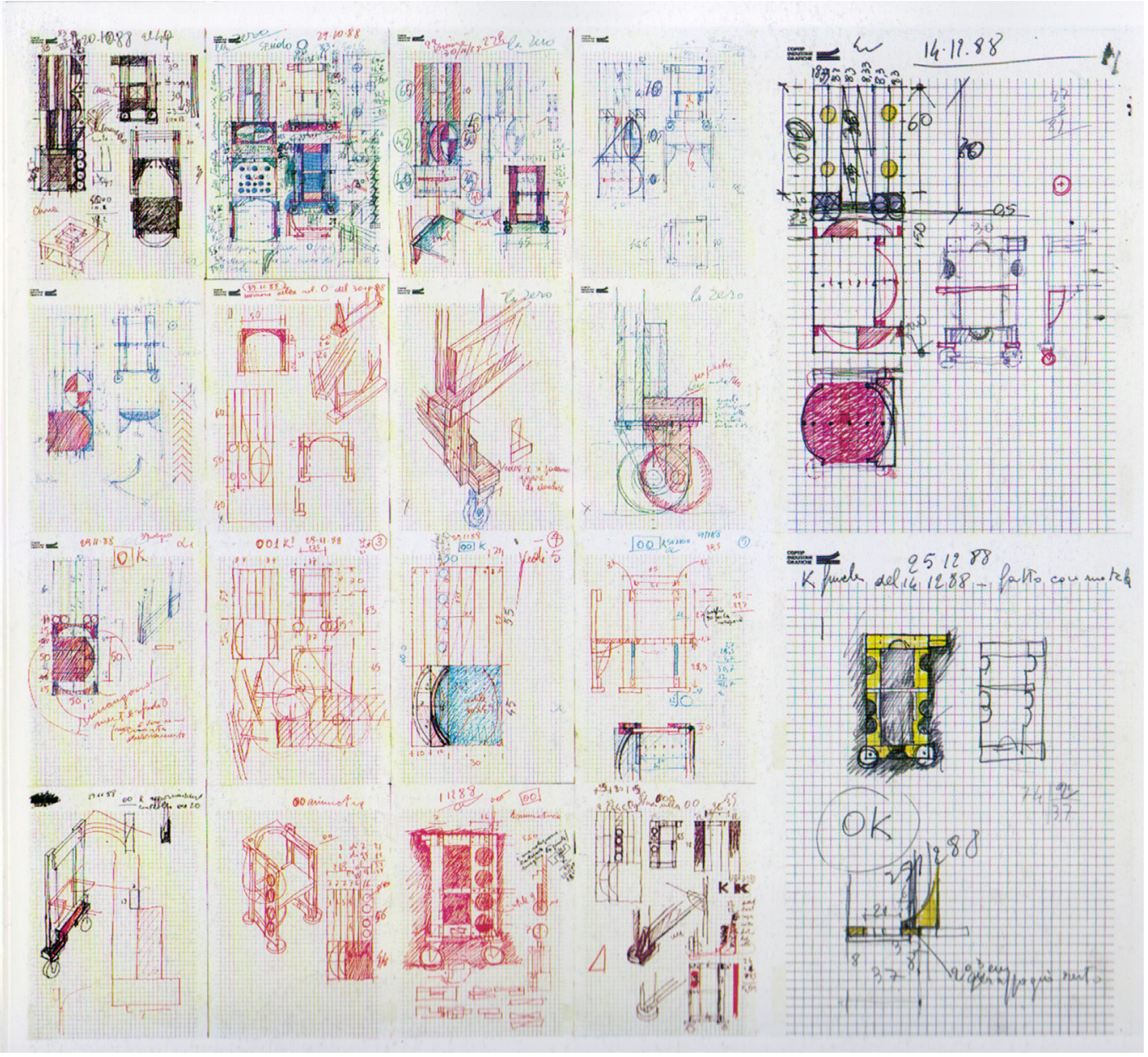

Dalla bidimensione alla tridimensione e viceversa

Nell'elaborazione di ogni prodotto, il pensiero dell'autore oscilla entro due campi d'azione: dal foglio di carta quadrettato su cui viene ipotizzata l'organizzazione delle figure nello spazio, alla tavola di legno su cui è trascritta la concatenazione degli elementi che andranno a configurare un nuovo volume. Così la tavola su cui sono impressi i tracciamenti diventa 


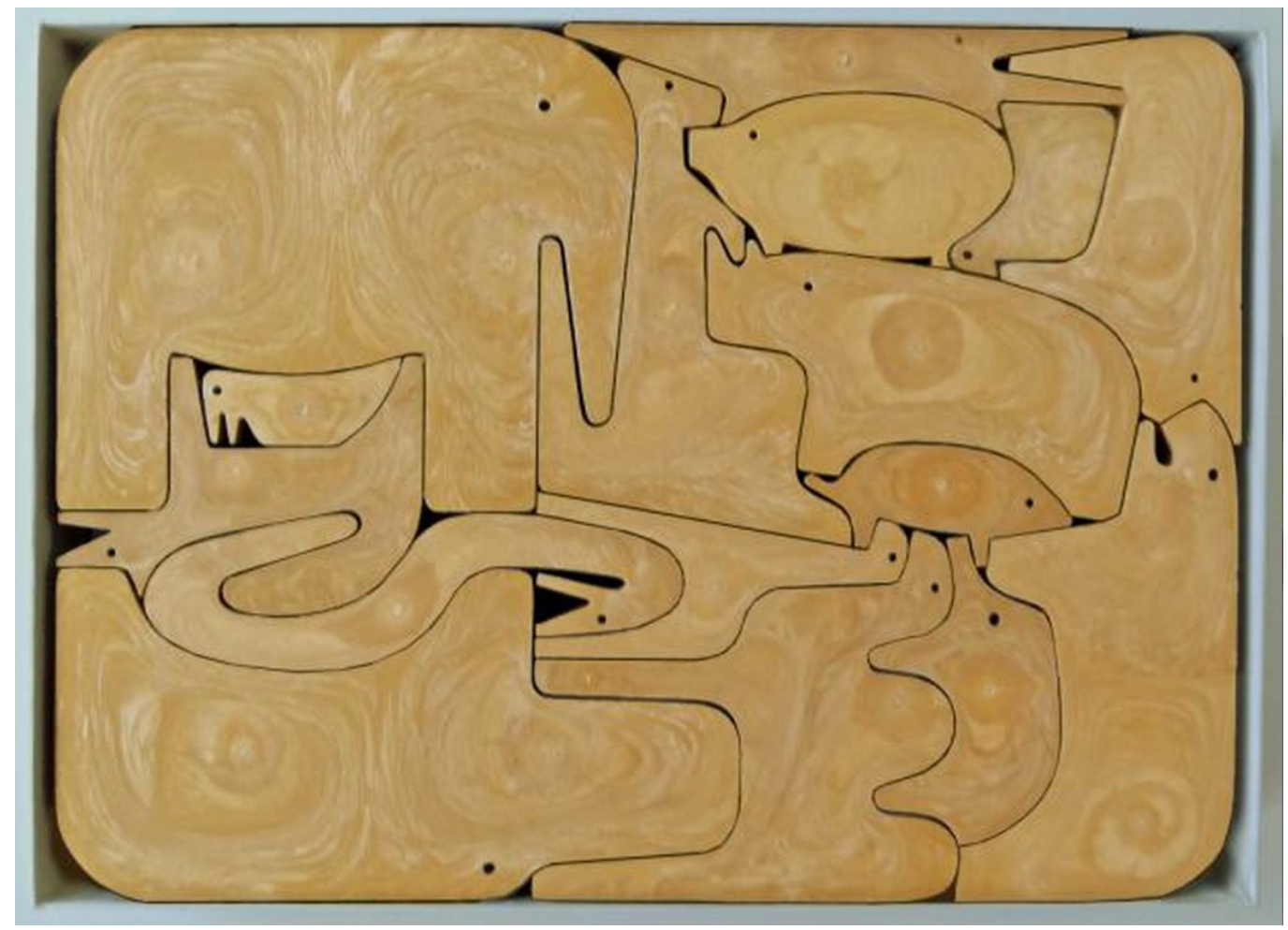

come nei puzzle di legno [Mari 2020 p. 36] un insieme che accoglie al suo interno tutte le parti interconnesse, svelando un legame indissolubile tra la parte e il tutto [Ugo |99| p. |27]. L'articolazione con cui si dispongono tutte le parti su un'unica superficie, segue linee di suddivisione che rendono evidente come non siano "gli elementi a determinare l'insieme ma l'insieme a determinare gli elementi" [Perec 2005, p. 7]. Per questo nei tracciamenti di Cesare Leonardi, la linea di contorno che accomuna più pezzi contigui all'interno di un insieme predefinito, non ha la stessa valenza che assume nei puzzle di legno (fig. 3). In quest'ultimi il contorno degli elementi si configura come il confine dove i pezzi torneranno a combaciare dopo essere stati sconnessi e disposti in un insieme disordinato mentre nei tracciamenti dei 'solidi' il bordo degli elementi è la linea di separazione tra i pezzi che assumeranno una precisa collocazione allinterno di un nuovo insieme spaziale (fig. 4). Questa sostanziale differenza induce a riflettere sull'importanza assunta dalla linea di contorno nel definire i rapporti proporzionali che legano le forme tra di loro e le relazioni esistenti tra l'immagine e l'identità degli oggetti.Come nei diagrammi lineari dei dipinti puristi (fig. 5), il profilo comune a più oggetti assume un duplice significato: da un lato unifica i diversi dati spaziali, dall'altro

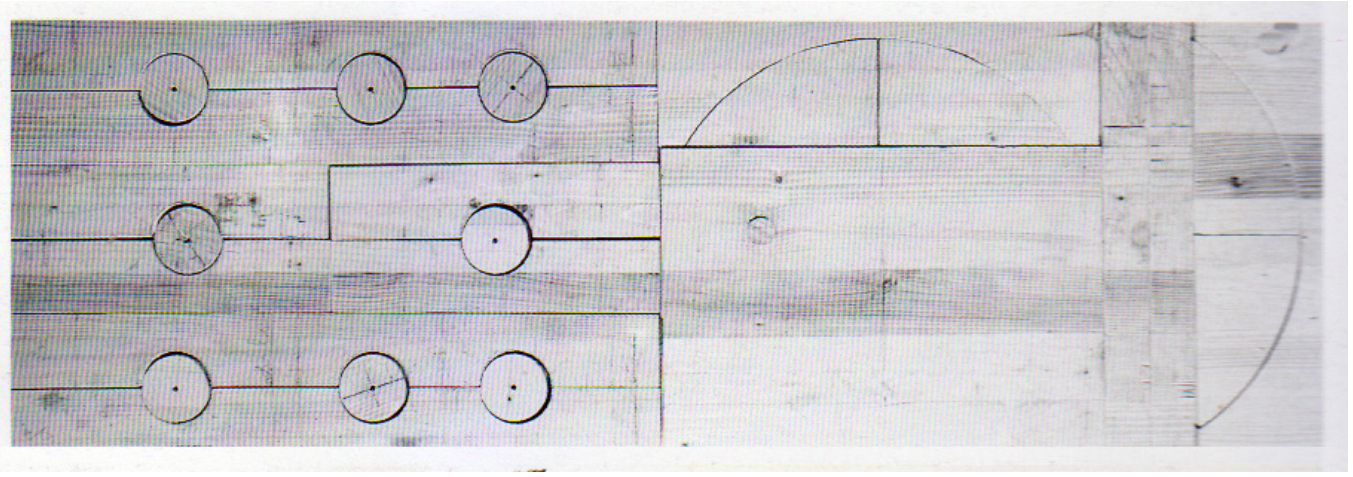


diventa un ordito che allude alla profondità di sagome che appaiono bidimensionali [Kepes 197I, p. I I I]. Sebbene nei tracciamenti dei 'solidi' le linee di bordo non si concatenino in un'ambiguità gestaltica, la linea separatrice assume la stessa forza dinamica presente nelle raffiguazioni puriste in quanto scaturisce dalla tecnica che l'ha generata [Arnheim 2009]. I segni impressi dalle macchine laser sulla tavola, sono le tracce dell'immagine in movimento, "immagine che nel progredire in funzione del tempo dà informazioni sulla collocazione-distribuzione della materia che forma l'oggetto" [Ambrosi 1992, p. 6]. Solo nel nuovo insieme, assemblato mediante connessioni puntuali, le immagini-identità dei pezzi che compongono il solido assumono una funzione plastica che ne giustifica la forma. Per questo Cesare Leonardi elabora sequenze di scatti fotografici ai prototipi da diverse angolazioni (fig. 6) non tanto per mostrare l'esito dei disegni di progetto, ma per usare la fotografia come un dispositivo di verifica della configurazione volumetrica ottenuta mediante un processo scultoreo [Miodini 2008, p. 4]. L'esito plastico raggiunto con la congiunzione di elementi bidimensionali secondo piani tra loro ortogonali è da intendersi come la riorganizzazione spaziale di un materiale che per trovare una sua traduzione volumetrica necessita di una suddivisione della superficie per potersi muovere. Infatti i segni che definiscono i tracciamenti su tavola diventano gli assi di rotazione o le traiettorie lungo le quali i pezzi posso essere traslati per trovare una collocazione finale nello spazio cartesiano.Le nuove immagini fotografiche realizzano, in un ritrovato spazio bidimensionale, un modello che solleva interrogativi formali e determina sensibili cambiamenti, cosi "ci sono tracciamenti diversi da quelli dettati dal progetto o pezzi dello stesso assemblati in modo completamente diverso dal tracciato : debolezza del disegno, precedenti momenti di lettura insufficienti da parte mia o capacità dei progetti di 'autoprogettarsi' presentandosi come sistemi polimorfi, acentrati?"' [ Leonardi 1993, p. 9]. Quello che Leonardi intende per 'progetto' è la sperimentazione formale contenuta nell'atto del disegnare, dello stabilire tracciati e sistemi di connessione che non si esaurisce con la rappresentazione dell'oggetto ma si trasforma, continuando a riverberare nell'assemblaggio del prototipo. In questa forma, il progetto spaziale "svela relazioni non apprese nel disegno e costruisce, al di fuori dell'atto intellettuale del rappresentare, un altro pensiero" [Viganò 2017, p. 178].

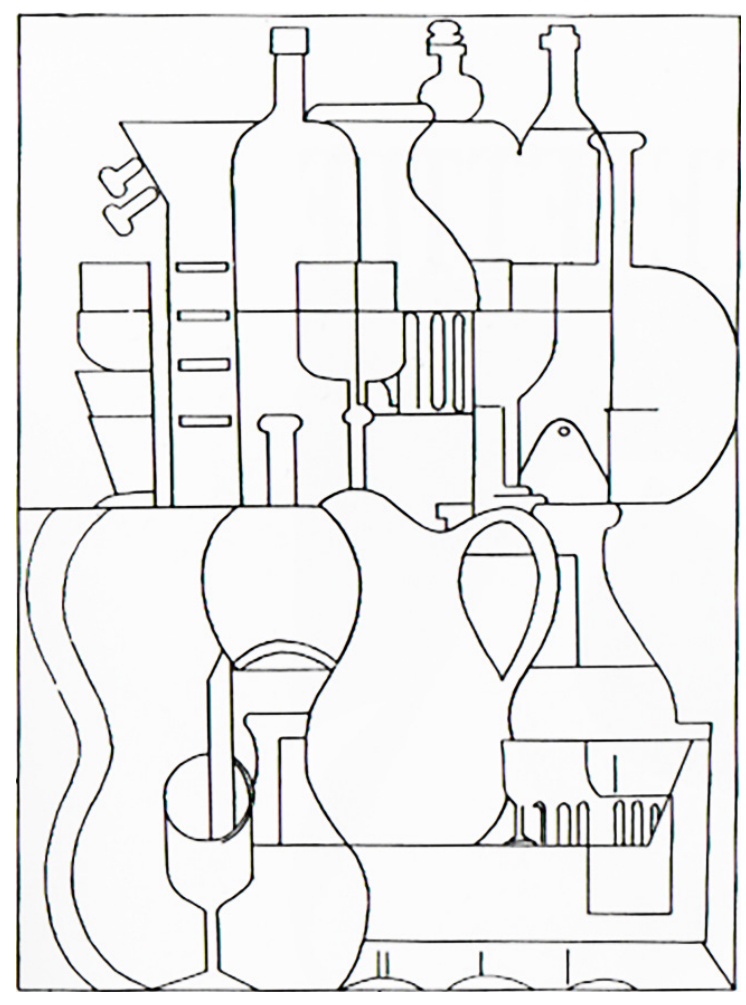




\section{Un'analisi grafica delle poltrone su ruote}

Questa costante oscillazione dalla superficie al volume e viceversa, oltre a essere una metodologia operativa che permette il controllo dell'esecuzione dell'oggetto, è soprattutto un attitudine del pensiero creativo a spostarsi da una dimensione a un'altra per trovare un punto di stasi quando la configurazione finale raggiunge un equilibrio.l processi plastico-figurativi sottesi alla ricerca formale di Cesare Leonardi e in particolare nei progetti di poltrone su ruote, potrebbero essere interpretati come una sequenza di operazioni che circoscrivono tutti gli elementi necessari a comporre una seduta, mediante azioni selettive attuate con il tracciamento di una linea che si sposta sul piano. La linea diventa così non solo l'ente che definisce la proiezione dell'oggetto ma anche la traiettoria con cui gli elementi vengono staccati dalla materia per diventare contorni concreti, stabilendo una stretta connessione tra realtà e rappresentazione. Da un'approfondita analisi grafica delle poltrone su ruote è stato possibile ricondurre il processo creativo a due tipi di diagrammi: quello delle operazioni sul piano e l'altro relativo alla definizione degli elementi (fig. 7). I due grafici sono concatenati tra di loro e stabiliscono una possibile successione temporale delle operazioni con cui vengono definiti i segni e gli elementi sulla superficie.La relazione con i limiti fisici del pannello di legno costuituisce il gesto primario con cui il designer proietta sulla tavola un'ipotesi di organizzazione della superficie che si può realizzare mediante azioni di riduzione, suddivisione, gerarchizzazione e frammentazione. In seguito alle diverse declinazioni con cui si attuano queste operazioni è possibile individuare una sequenza di azioni volte a dare una riconoscibilità formale agli elementi. II primo elemento che viene definito è la seduta che può insistere all'interno del modulo, coincidendo con quest'ultimo o definendosi come una figura inscritta, sagomata o frammentata. Essendo il nodo di connessione tra tutte le parti della poltrona, l'individuazione della seduta implica la definizione dei fianchi, che assumono i profili più variegati a seconda dell'aspetto che l'oggetto assumerà in elevato. II contorno dei fianchi viene estratto dalla parte restante del tavolato, mediante suddivisioni geometriche che si sviluppano per complementarità, specularità, rotazione, frammentazione, sottrazio-

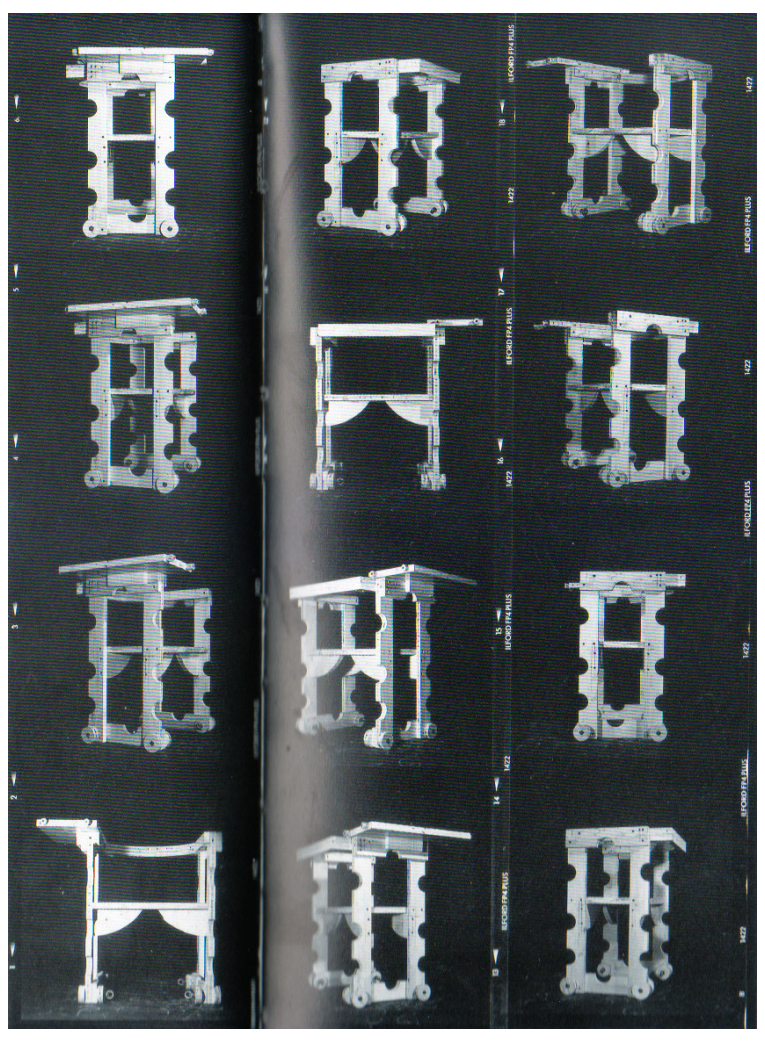


Fig. 7. Diagramma delle operazioni sul piano e della definizione degli elementi per la costruzione del tracciamento.

Fig. 8. Schemi evolutivi del tracciamento della PRL04. ne, inscrizione o coincidenza con i moduli restanti, determinando gli elementi della figura prevalente. Le parti residue del pannello, non ancora disegnato, diventano così i nuovi spazi da cui ottenere lo schienale e le connessioni che rendono possibile la stabilità dell'oggetto nella sua configurazione volumetrica. Lo schienale per la sua particolare funzione all'interno dell'oggetto viene ricavato, rispetto ai fianchi o la seduta, per complementarità o indipendenza formale, mentre le connessioni sono il risultato di una sottrazione di materiale da elementi appena definiti o per integrazione rispetto ad altri pezzi.Volendo esplicitare il processo grafico della poltrona su ruote PRL04 ricavata da un pannello composto da tre moduli quadrati $50 \times 50 \mathrm{~cm}$ si potrebbe avanzare che la seduta sia stata ottenuta mediante uno slittamento del modulo di base lungo l'asse longitudinale per definire una gerarchizzazione della superficie del pannello che così risulta composto da tre aree differenti. All'operazione di riduzione del modulo seduta, mediante la rifilatura che definisce un'ulteriore superficie residua, segue una suddivisione della superficie superiore in campi rettangolari di egual misura che definiscono i fianchi mediante una sequenza di rettangoli chiusi. Le due porzioni disposte ortogonalmente tra loro, in prossimità della seduta, diventano ora le aree da cui estrarre i profili doppi dello schienale e le connessioni, per complementarità da quest'ultimi. Gli elementi circolari sottratti alle fasce dei fianchi completano la sequenza di operazioni diventando le ruote poste alla base (fig. 8).

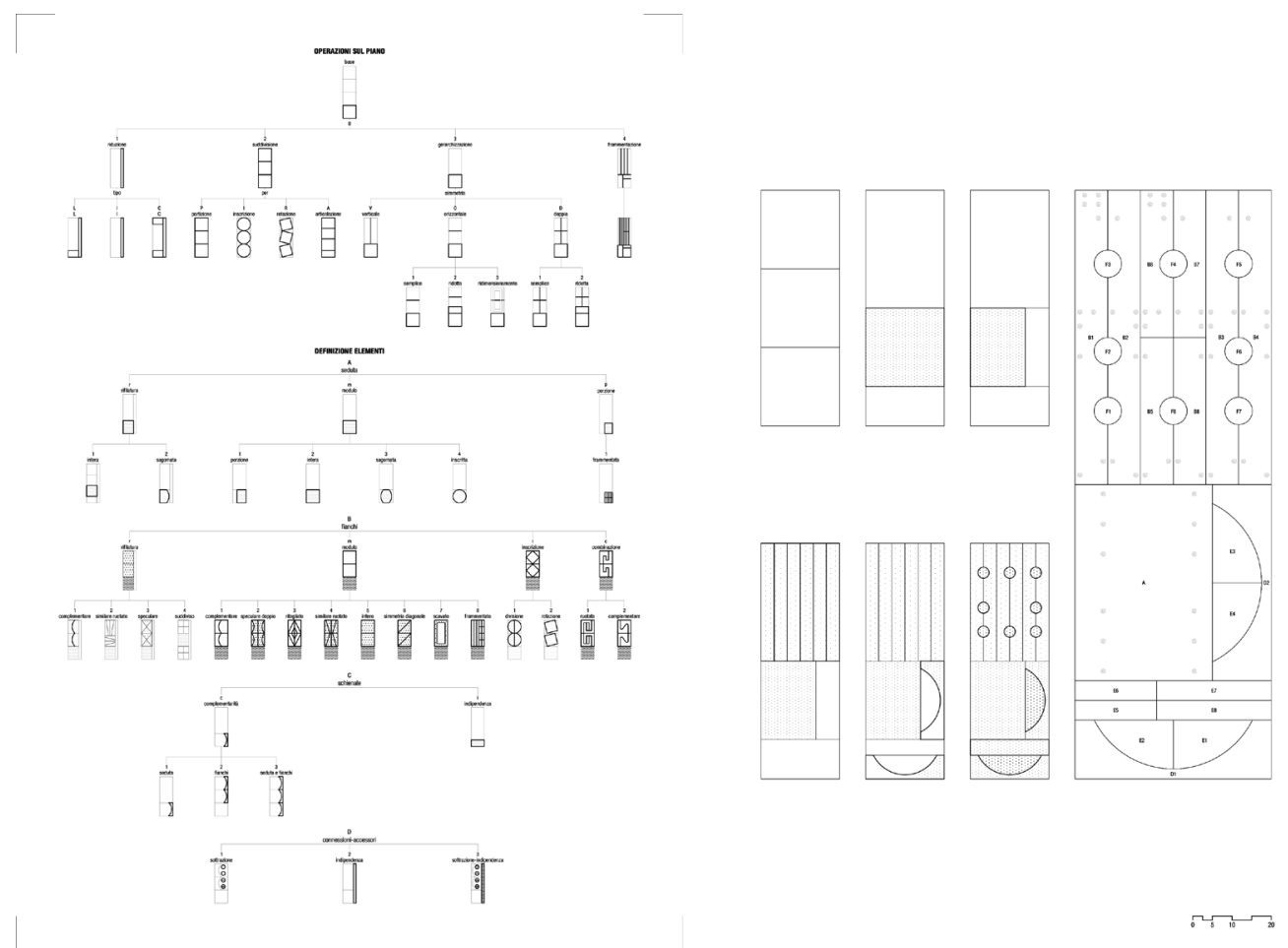

A questo processo generativo di tipo geometrico-proporzionale segue quello di montaggio del 'solido' che si struttura su logiche aggregative principalmente fondate su movimenti di traslazione e rotazione che portano lentamente a svuotare la superficie mediante una sequenza di sottrazioni, per contorni definiti, fino a costruirne il volume (fig. 9). Questa scomposizione analitica di fasi di tracciamento e assemblaggio che nella rappresentazione appena illustrata appare come una sequenza logica e lineare, non è altro che la visualizzazione grafica dell'ultima fase di affinamento che l'oggetto ha ricevuto dal suo autore durante il processo creativo e che mette in luce la sua condizione di equilibrio formale tra le parti e il tutto (fig. 10). La migrazione della materia da una dimensione superficiale a una volumetrica può essere così intesa come un processo metamorfico sostenuto da un dispositivo immaginativo che Cesare Leonardi ha elaborato per rendere visibile la molteplicità formale contenuta nell'unicità di un banale pannello di legno (fig. I I). 
Fig. 9. Fasi di montaggio della PRL04. Fig. I0. Esploso assono-
metrico della PRL04
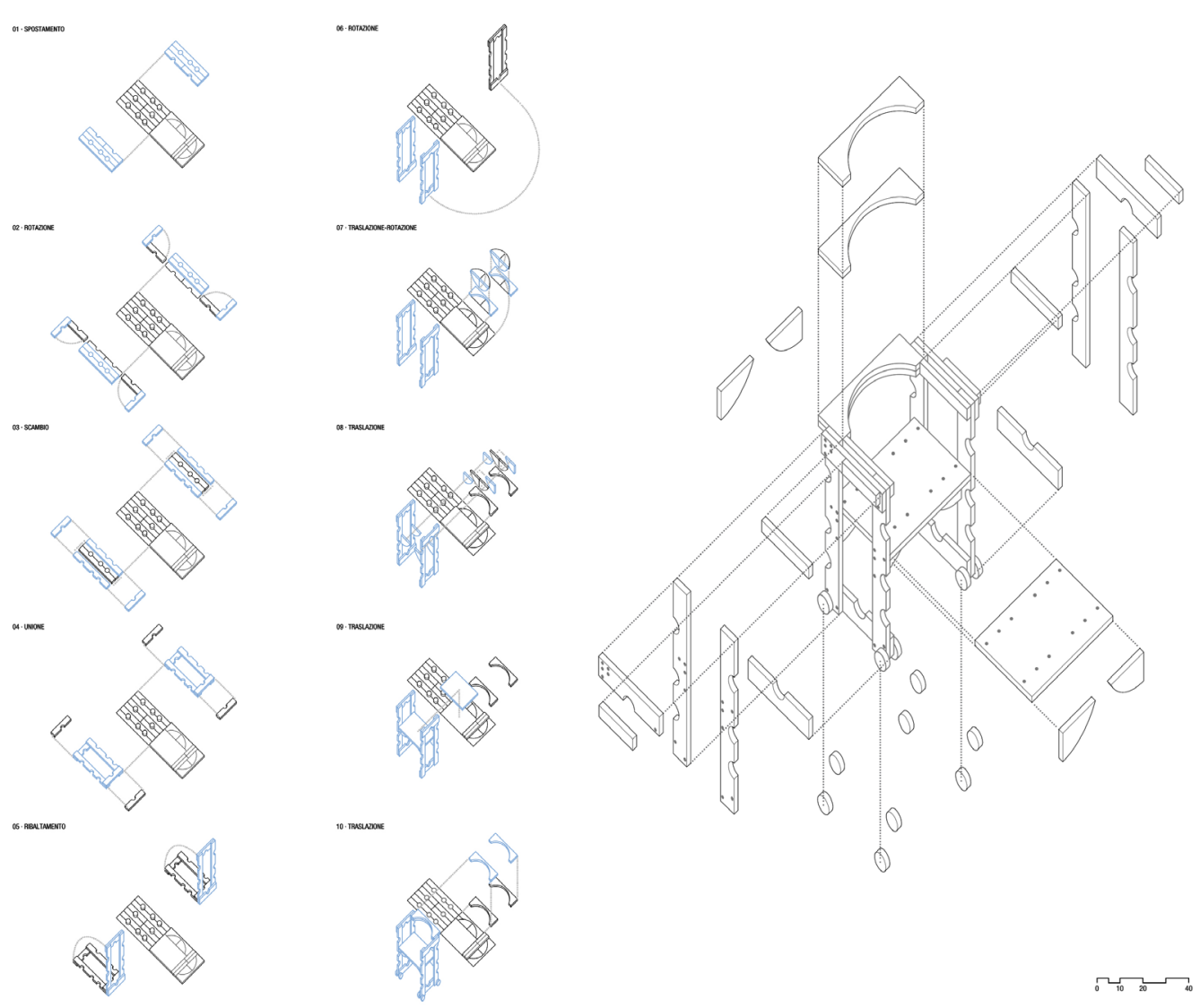

$$
\text { (n) }
$$




\section{Riferimenti bibliografici}

Ambrosi A. (1992). Gli oggetti e le loro rappresentazioni. In A. Ambrosi et al. (a cura di). Geometria e Percezione nei Metodi di Rappresentazione Grafica, pp. 5- I8. Bari: Edipuglia.

Anceschi G. (1992). L'oggetto della raffigurazione. Milano: Etas.

Arnheim R. (2009). Arte e percezione visiva. Milano: Feltrinelli.

Cavani A., Orsini G. (a cura di). (2017). Cesare Leonardi. L'architettura della vita. Barcellona: lazy dog.

Di Napoli G. (2004). Disegnare e Conoscere. La mano, l'occhio, il segno. Milano: Einaudi.

Dorfles G. (2003). Artificio e Natura. Milano: Skira.

Elia M. (2008). VChUTEMAS. Design e avanguardie nella Russia dei Soviet. Milano: Lupetti.

Kepes G. (197I). II linguaggio della visione. Bari: Dedalo.

Klee P. (2009). Teoria della forma e della figurazione. Vol. I: II pensiero Immaginale. Milano: Mimesis.

Leonardi C. (1976). Fotografie 1950// 976. Catalogo della mostra.

Leonardi C., Stagi F. (20 I 8). L'architettura degli Alberi. Barcellona: lazy dog.

Maldonado T. (20।0). Arte e artefatti. Milano: Feltrinelli.

Maldonado T. (20 I5). Disegno industriale: un riesame. Milano: Feltrinelli.

Maldonado T. (2015). Reale e Virtuale. Milano: Feltrinelli.

Mari E. (2020). 25 modi per piantare un chiodo: Sessant'anni di idee e progetti per difendere un sogno. Milano: Oscar-Mondadori.

Martinelli G. (a cura di) (1994). Cesare Leonardi: Solidi-Solids 1983-1993. Modena: Logos.

Miodini L. (2008). Memoria e Sguardo della scultura. In WunderKammer (a cura di). Cesare Leonardi-Scultura. Catalogo della mostra.

Perec G. (2005). La vita istruzioni per l'uso. Milano: BUR.

Rossi A. (2005). Disegno Design. Natura morta e vita metafisica. Roma: Officina Edizioni.

Sennet R. (2019). L'uomo artigiano. Milano: Feltrinelli.

Ugo V. (199I). I luoghi di Dedalo. Bari: Dedalo.

WunderKammer (a cura di). (2008). Cesare Leonardi-Scultura. Catalogo della mostra.

\section{Autore}

Domenico Pastore, Politecnico di Bari, domenico.pastore@poliba.it

Per citare questo capitolo: Pastore Domenico (2021). Dalla superficie al volume. Un'indagine grafica del progetto Solidi di Cesare Leonardis/ From surface to solid. A close reading about Cesare Leonardi's project Solids. In Arena A. Arena M. Mediati D. Raffa P. (a cura di). Connettere. Un disegno per annodare e tessere. Linguaggi Distanze Tecnologie. Atti del $42^{\circ}$ Convegno Internazionale dei Docenti delle Discipline della Rappresentazione/ Connecting Drawing for weaving relationship. Languages Distances Technologies. Proceedings of the $42^{\text {th }}$ International Conference of Representation Disciplines Teachers. Milano: FrancoAngeli, pp. 945-962. 


\title{
From Surface to Solid. A Close Reading about Cesare Leonardi's Project Solids
}

\author{
Domenico Pastore
}

Abstract

In the early 1980s, Cesare Leonardi initiated the project Solids that was focused on a clear aim: reuse the panels which were previously employed for reinforced concrete formworks in order to assemble original household furniture. No additional material was needed, while the surface of the modular panel to be repurposed was maximized. After defining the physical limitations and characteristics of the base material, Leonardi imagined a spatial articulation of pieces that would set up different types of armchairs or coffee tables. This research aims to provide an interpretation of the figurative process that transforms diverse volumetric shapes, each with a peculiar function, which eventually form a volumetric outcome by two-dimensional tracing and measuring operations. Through a graphic-analytical investigation of the types of armchair with wheels, we will try to decode recurring actions and methods to define the elements that determine all the different configurations designed by Leonardi.

Keywords

graphical analysis, drawing, design, diagram, figuration.
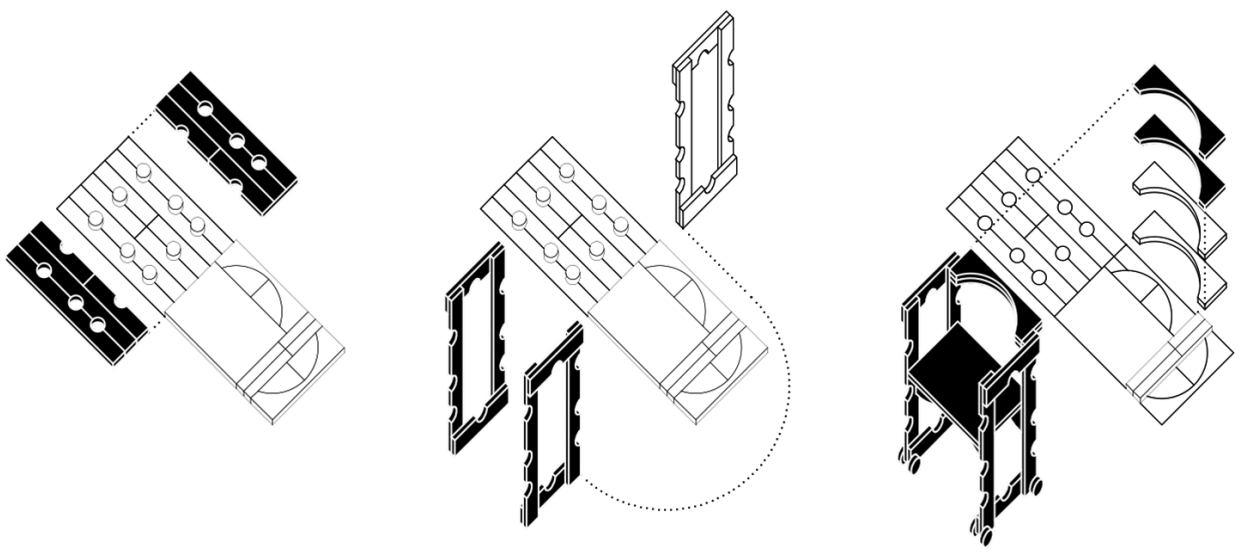


\section{Cesare Leonardi’s project Solids}

In the early 1980s, Cesare Leonardi initiated a research project about design, centered on the reuse of the panels which were previously employed for reinforced concrete formworks in order to assemble original household furniture.

The objects which have been drawn from 1983 to 1993 are listed in the book entitled Solidi/Solids. The principle behind these works is the same: "they had to be made from the standard wooden formwork or shuttering board used for concrete wall construction, with all its intrinsic limitations and without recourse to any other material" [Martinelli, I 993 p. 7]. This fundamental principle, focused on the physical and material limits, is paired with a second one about the recipient. As a matter of facts, all the works have been thought to please only the designer and the maker who is building them, not to satisfy a customer, alien to the creative process.

The exclusion of the customer and the correspondence between client and designer/contractor make this research a proper artistic project where the human primitive impulse to create objects express itself in the realization of physical things through the manipulations of elements available in the reality, creating "anything different from what existed before" [Dorfles 2003, p. 43].

The production of an object through the metamorphosis of a semifinished part -like a preformed wooden panel- requires a complex inventive project since it forced to imagine the object not as a figure but as a process that defines a three-dimensional configuration, different from the usual concretizations of a picture born as "immediate data" [Anceschi 1992 p. 22].

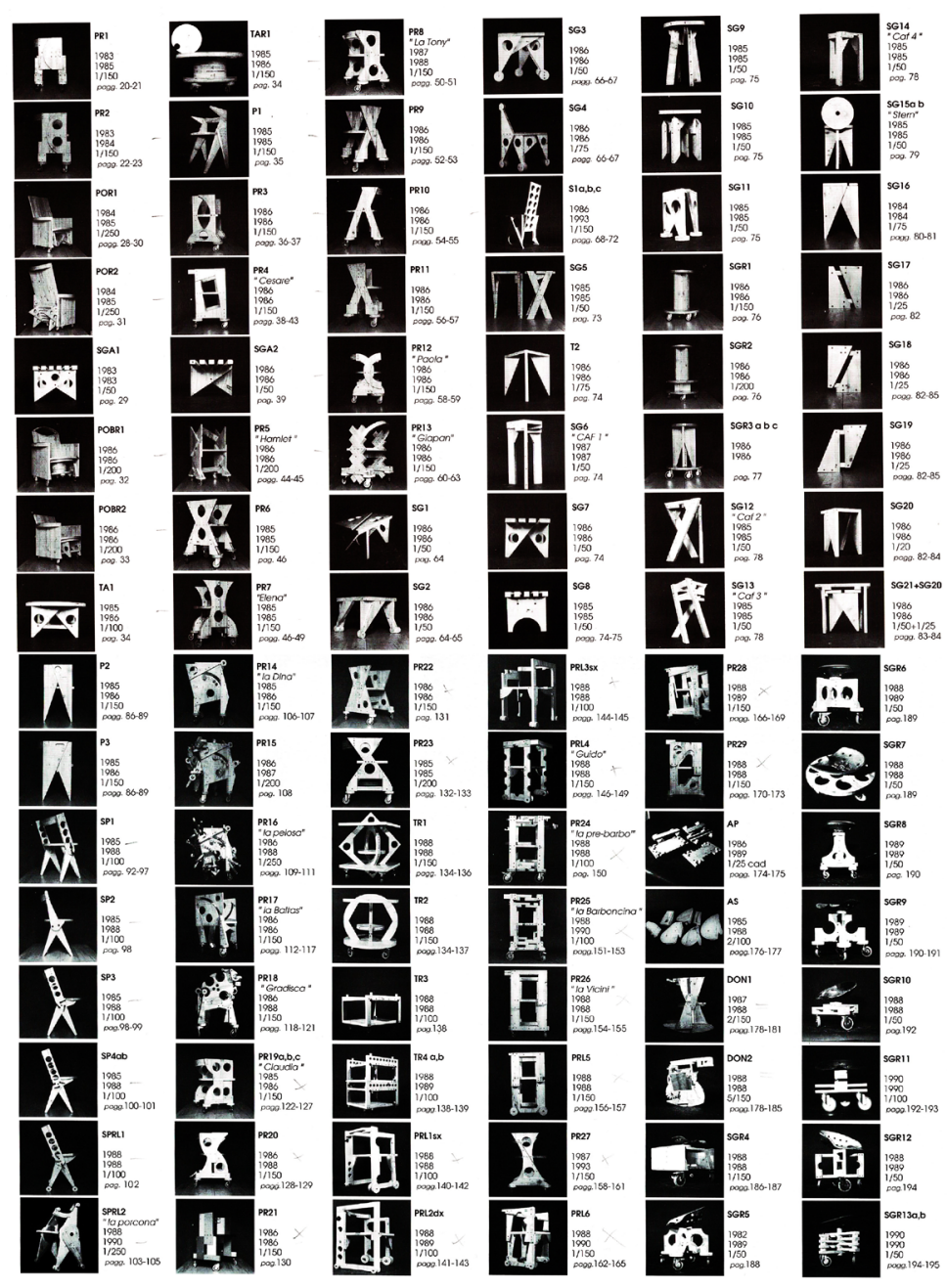


The self-imposed use of a single material and the maximization of the useful surface in order to extract all the parts composing the Solid, define the necessary conditions in which Cesare Leonardi works to develop a series of objects - different in shapes and functions (fig. I). The descried creative process, characterized by prefixed conditions, could be interpreted as a research to verify the limits and the imaginative potentials of the craft-man [Sennet 2019 p. 27] who denotes the construction of new objects into a reflective practice, rather than a method to optimize the construction of a product [Leonardi 1993, p. 9].

In this context, every solid is already entirely contained in the panels and the work of the designer is to extract it differently, applying each time a principle to transpose the two-dimensional space into a three-dimensional one. This process does not develop in a single direction from the cutting path to final configuration, but can be modified by several transformations due to machining constraints. As an example, the rough sketches on squared paper represent cutting path schemes and orthogonal projections, followed by general and particular axonometric drawings to explain the transformation of the project from the two-dimensional representation to the three-dimensional reality (fig. 2).

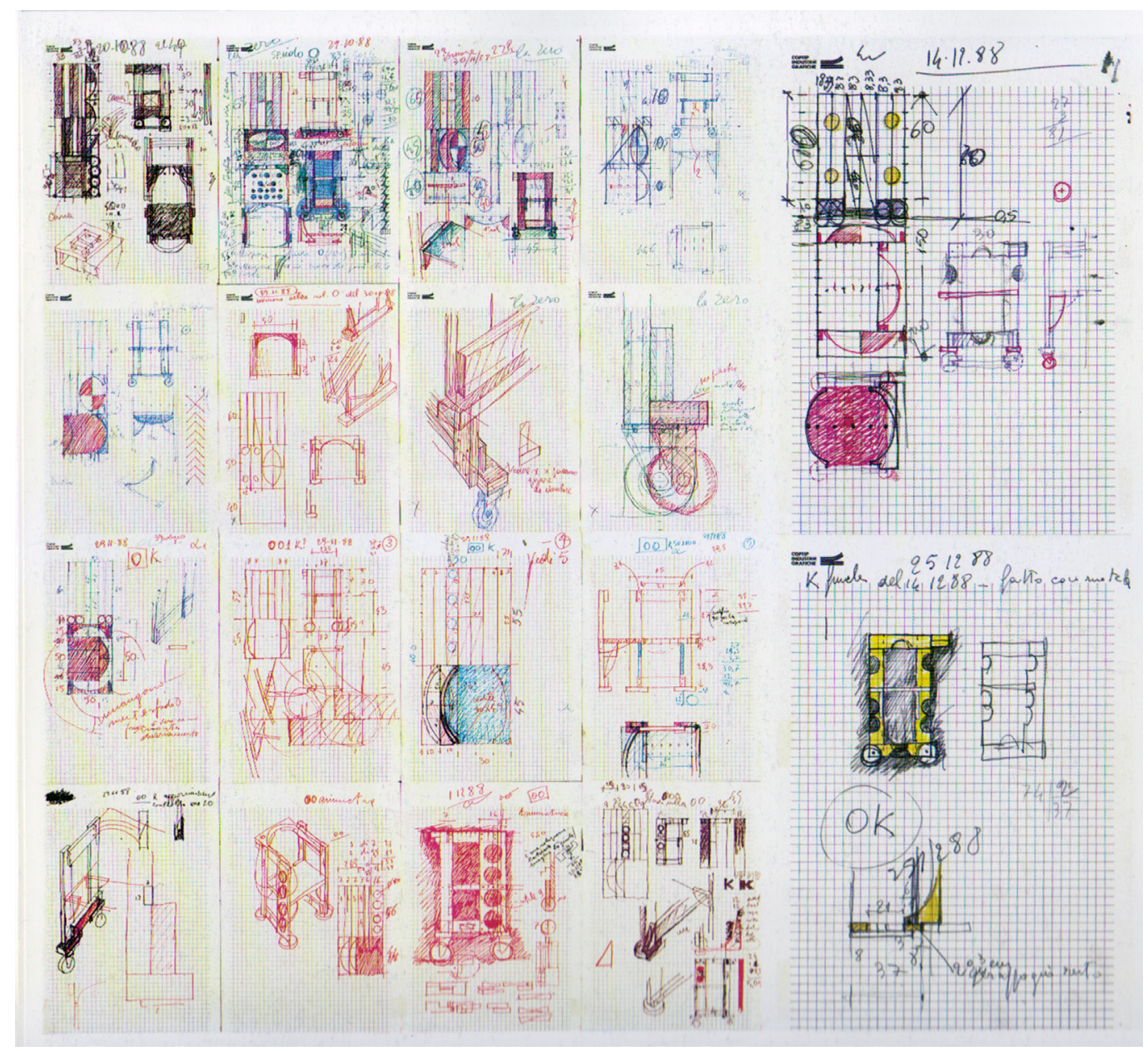

\section{From two to three-dimension, and back}

In the processing of a product, the author's mind is focused on two main areas: from the squared paper where the organization of the figures in the space is defined, to the wooden panels where the inlay of the elements defining the new volume is transferred. 
Fig. 3. The cluster puzzle of the 16 animals by Enzo Mari.

Fig. 4. Drawing for PRLO4 [Martinelli 1994, p. 146]

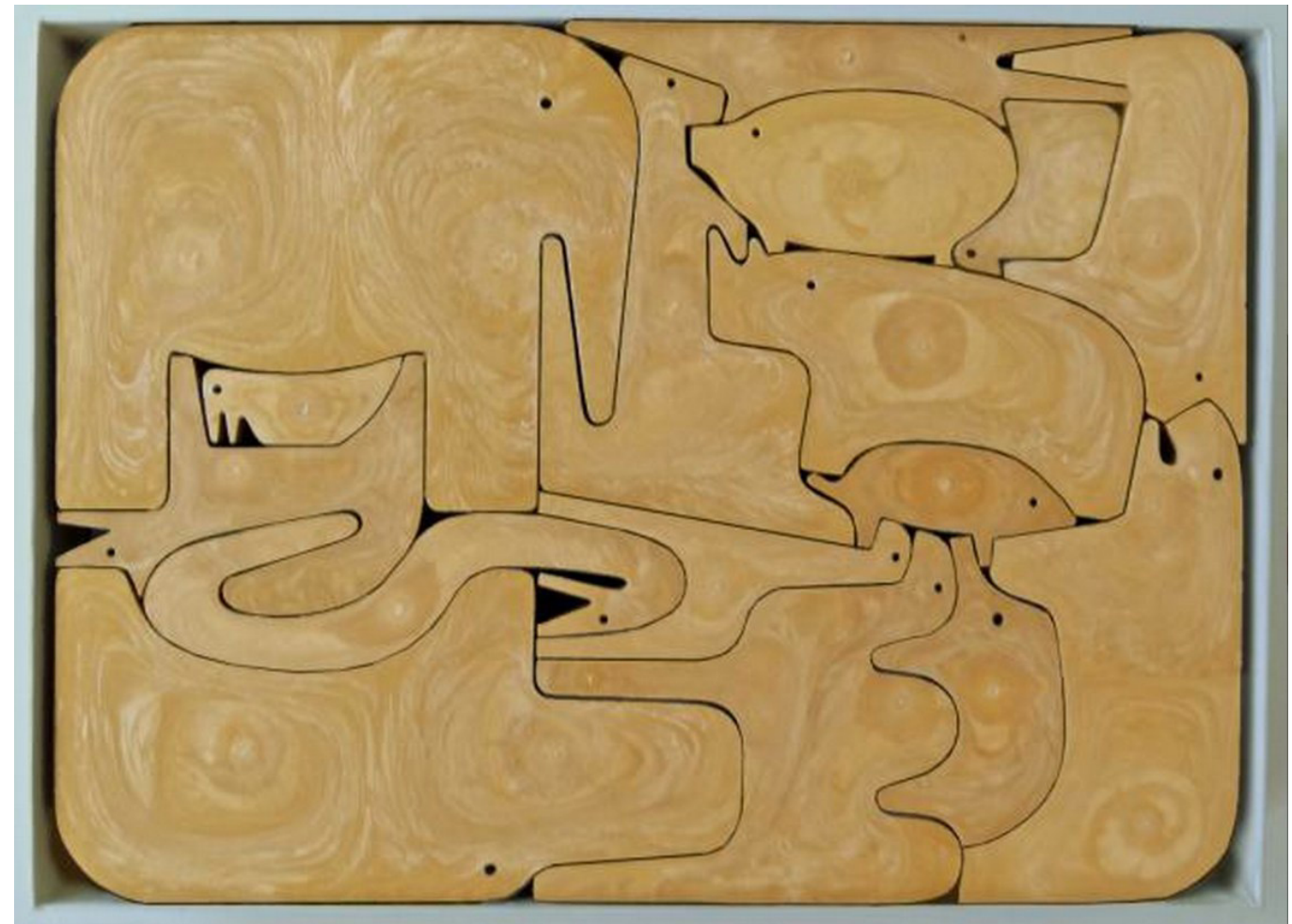

The wooden panel with the cutting paths becomes a wooden cluster puzzle [Mari 2020, p. 36], a collection of independent but interconnected shapes, where the absolute connection between the part and the whole is revealed [Ugo |99|, p. I27]

The layout of the parts on the same surface is defined by lines which does not make "the elements to determine the whole, but the whole to determine the elements" [Perec 2005, p. 7]. For this reason, in Cesare Leonardi's sketches, the contour line shared by adjacent parts in a pre-defined space differs from the one in wooden puzzles (fig. 3).

In the latter, the contour lines define a border where the parts shall recombine after being spread. On the other hand, in the drawings in 'solids' the boundary of the elements is the separation line between parts which will take a precise place in a new space (fig. 4).

Questa sostanziale differenza induce a riflettere sull'importanza assunta dalla linea di contorno nel definire i rapporti proporzionali che legano le forme tra di loro e le relazioni esistenti tra l'immagine e l'identità degli oggetti.

This crucial difference marks the importance of the contour line in determining the proportional ratios between the forms and the relationship between the drawing and the objects.

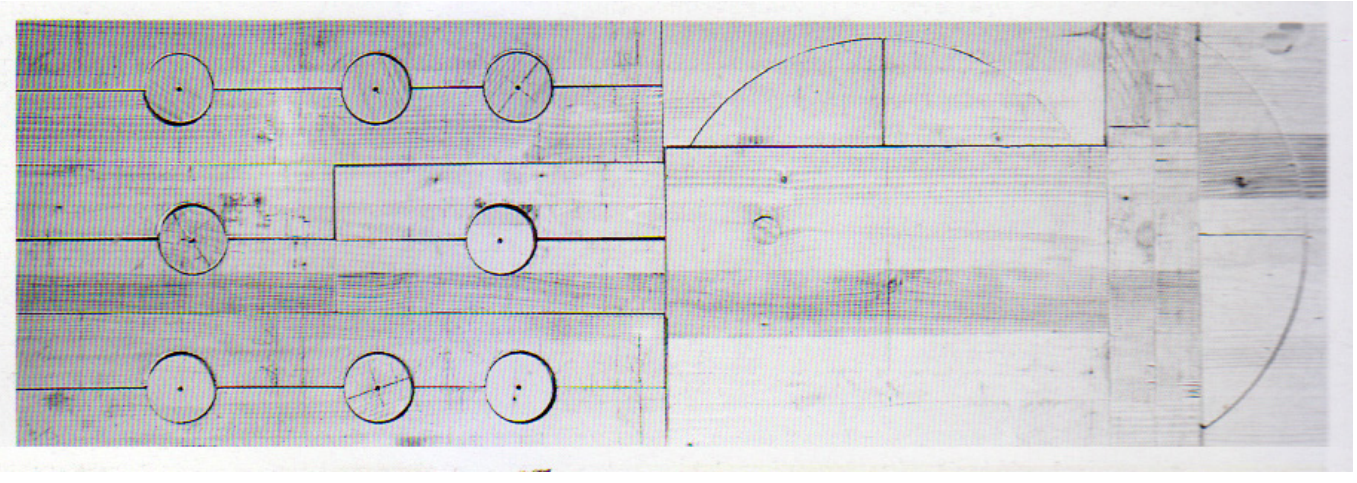


Like in the linear diagrams of the purist portraits (fig. 5), the profile shared among several objects brings a double meaning: on one hand unifies the different spatial elements, on the other becomes the graphical element which gives depth to the bidimensional silhouette [Kepes 1971, p. I I I]. Even if in cutting paths of 'solids' the contour lines does not create a Gestaltic ambiguity, the separation mark brings the same dynamic force of the purist portraits, arising from the technique which generated it [Arnheim 2009].

The marks impressed by the laser cutting machine on the wooden panels represent the pictures in motion, " a picture which progress in time provide informations on the place and distribution of the matter that compose the object" [Ambrosi, 1992, p. 6]. Only in the resulting creation, assembled as a whole by punctual connections, the identity-figures of the parts which compose the solid assume the plastic function to justify the form.

As a matter of fact, Cesare Leonardi takes a series of photographs of the prototypes from different points of view (fig. 06) not only to show the result of his works but in order to use the pictures to check the volumetric configuration obtained through a sculptural process [Miodini 2008, p. 4]. The plastic result obtained by the intersection of bidimensional elements in orthogonal planes can be intended as the spatial re-organization of a material that needs a definition on a surface in order to move into a volume.

Indeed, the marks on the sketches in the panels become the rotational axes or the trajectories along which the parts can be moved to find their place in the Cartesian plane. Le nuove immagini fotografiche realizzano, in un ritrovato spazio bidimensionale, un modello che solleva interrogativi formali e determina sensibili cambiamenti, così "ci sono tracciamenti diversi da quelli dettati dal progetto o pezzi dello stesso assemblati in modo completamente diverso dal tracciato : debolezza del disegno, precedenti momenti di lettura insufficienti da parte mia o capacità dei progetti di 'autoprogettarsi' presentandosi come sistemi polimorfi, acentrati?" [Leonardi, 1993, p. 9]. The new photographs realize, for the second time in a two-dimensional space, a model which arises formal questions and determines sensible changes "So we get outlines differing from those dictated by design itself or find its pieces assembled in an entirely different way from the traced pattern. In the reason for this to be sought in a design weakness, a faulty reading on my part at earlier stages, or an ability of the

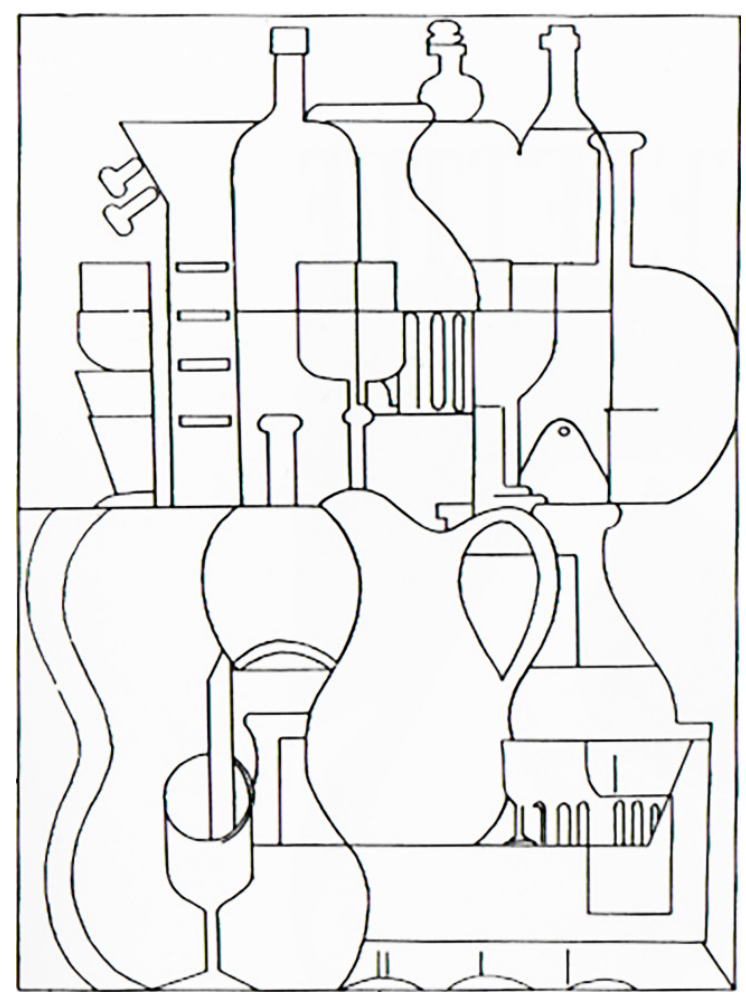


drawings to "design themselves", emerging as a polymorphous, a-centered system?" [Leonardi 1993, p. 9]. The meaning of this project for Leonardi is the artistic research of the act of drawing, the marking of sketches, and connection systems which do not complete in the simple representation of the object but transform into the assembly of the prototype. According to this view, the spatial project "reveals relationship hidden in the drawings and build another thought, external to the intellectual act of representation" [Viganò 2017, p. 178].

\section{A graphical analysis of the armchairs on wheels}

The oscillation between surface and volume - and vice-versa - more than being a methodology to check the execution of the object, is a creative attitude to move from a dimension to another in order to find an equilibrium when the final configuration achieves a balance. The figurative plastic processes behind Leonardi's artistic research and in particular the project with armchairs on wheels could be interpreted as a sequence of operations that define all the elements necessary to compose a seat through selective actions made by drawing a line on the plane. This line is not only the element that traces the projection of the object but also the trajectory by which the parts are separated to become real objects, establishing a connection between reality and representation.

Using a deep graphical analysis of the armchairs on wheels, this paper describes Leonardi's creative research with two types of graphs: the tree diagram of the operations on the plane and the tree diagram of the definition of the parts (fig. 7).

The two graphs are related to each other and define a possible evolution in time of the operations which define the marks and the elements on the surface. The relation with the physical limits of the wooden panels forms the primary act used by the designer to project on the table the ideas of organizations on the surface, which could be realized with actions of: reduction, partition, hierarchization, fragmentation.

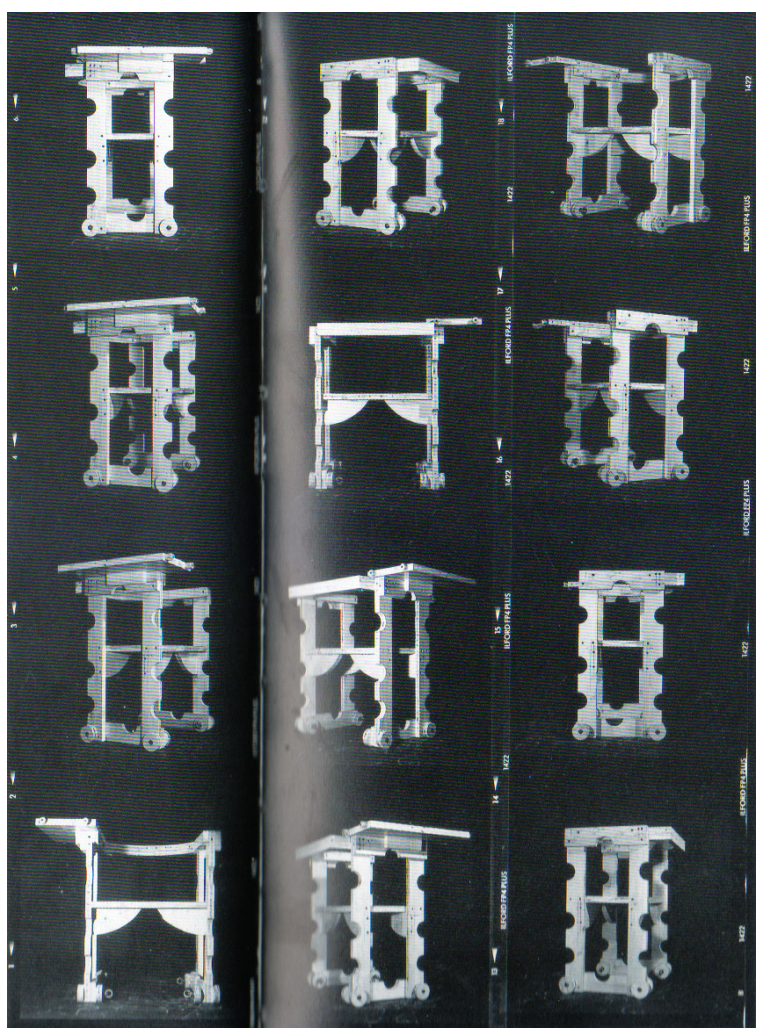


Fig. 7.Tree diagrams of the operations on the plane for the construction of the sketching.

Fig. 8. Evolution of the cutting paths for PRLO4 (credits to Mikel Xeka)
The different declinations of these actions could define a sequence that creates the elements. The first part to be outlined is the seat which can be the whole module or inscribed, delimited, and fragmented in it. The seat is the center of connection for the other elements of the armchair and it defines the arms which could take different profiles according to the shapes of the object in the space. The contour of the arms is extracted from the remaining parts of the panel, according to the following geometrical partitions: complementarity, specularity, rotation, fragmentation, subtraction, inscription, and connection. The remaining sections of the panel, free of sketching, become new spaces to obtain the backseat and the connecting parts which make possible the stabilization of the final object in the volume.

Due to its specific function in the object, the backseat is usually defined by complementarity or independently marked. The connecting parts result from the subtraction of material from elements or by integration with other parts. As an example, in the graphic process of the armchairs on wheels PRL04 - built with three module panels $50 \times 50 \mathrm{~cm}$-, the seat could be obtained by sliding the base module on the longitudinal axis, introducing a hierarchization of the panel in the different areas. The module of the seat is refined creating a residual surface which is partitioned in rectangular section of the same size which defines the arms as a sequence of closed rectangles. The two partitions oriented orthogonally to each other close to the seat becomes the areas where to extract the double profiles of the backseat and

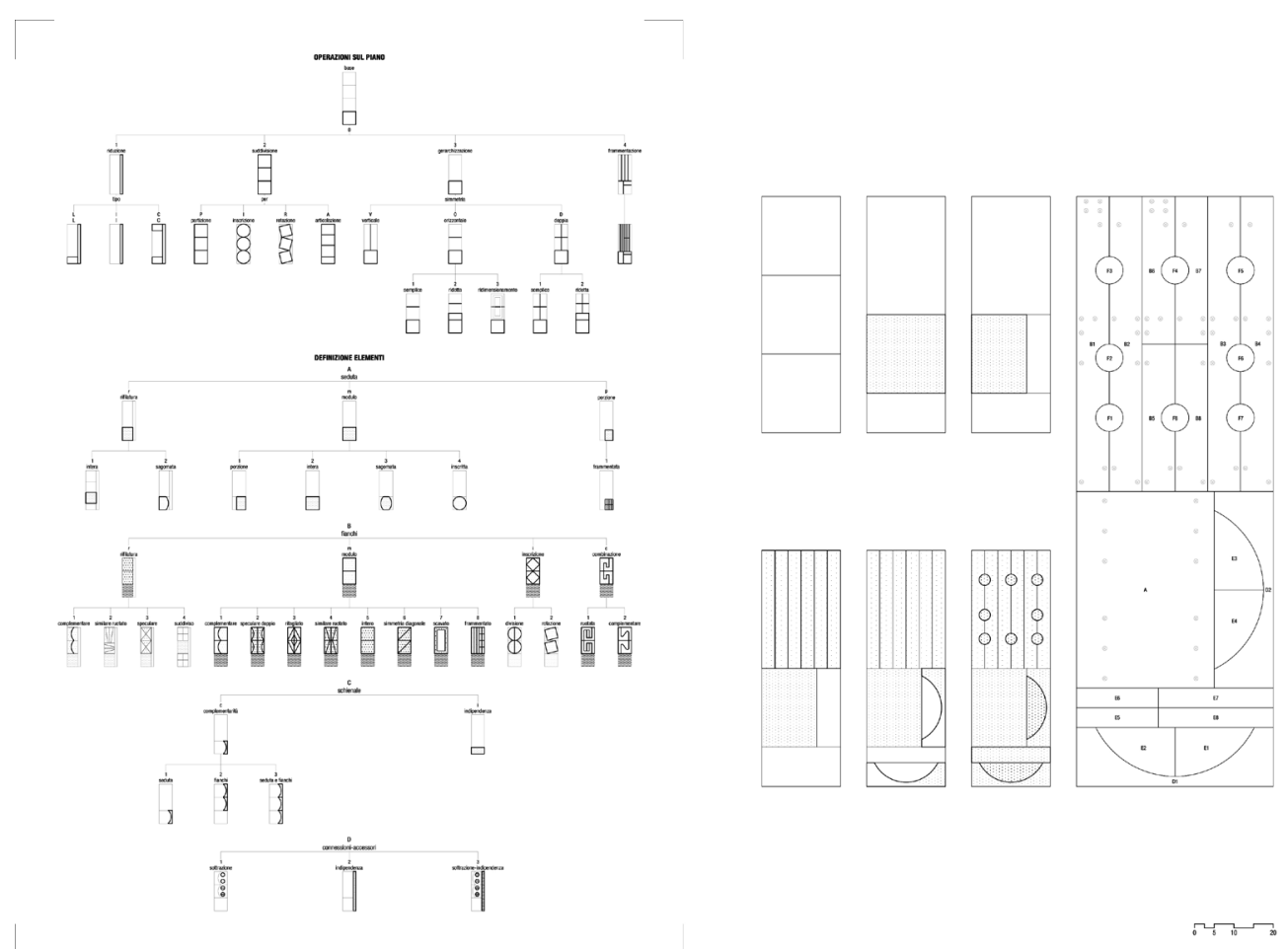

the connecting parts - by complementarity with the latter. The circular elements inscribed in the areas below complete the sequence of operations becoming the wheel at the base of the armchair (fig. 8).

The proportional-geometric process which generates on the panels is followed by the assembly of the Solido according to a scheme of aggregations based mainly on translation and rotation which dismantles the surface using subtraction until the volume is created (fig. 9). The analytical decomposition in sketching phases and assembly which appear as a schematic and linear logic as depicted before, in reality, is the visualization of the refinement which the object has received by the author during the creative process and it highlights the balance between the whole and the parts (fig. I0).

The migration of matter from a plane dimension to a volume can be described as a metamorphic process testified by the imaginative tool which Cesare Leonardi has designed in order to show the multiplicity within unicity of a simple wooden panel (fig. II). 


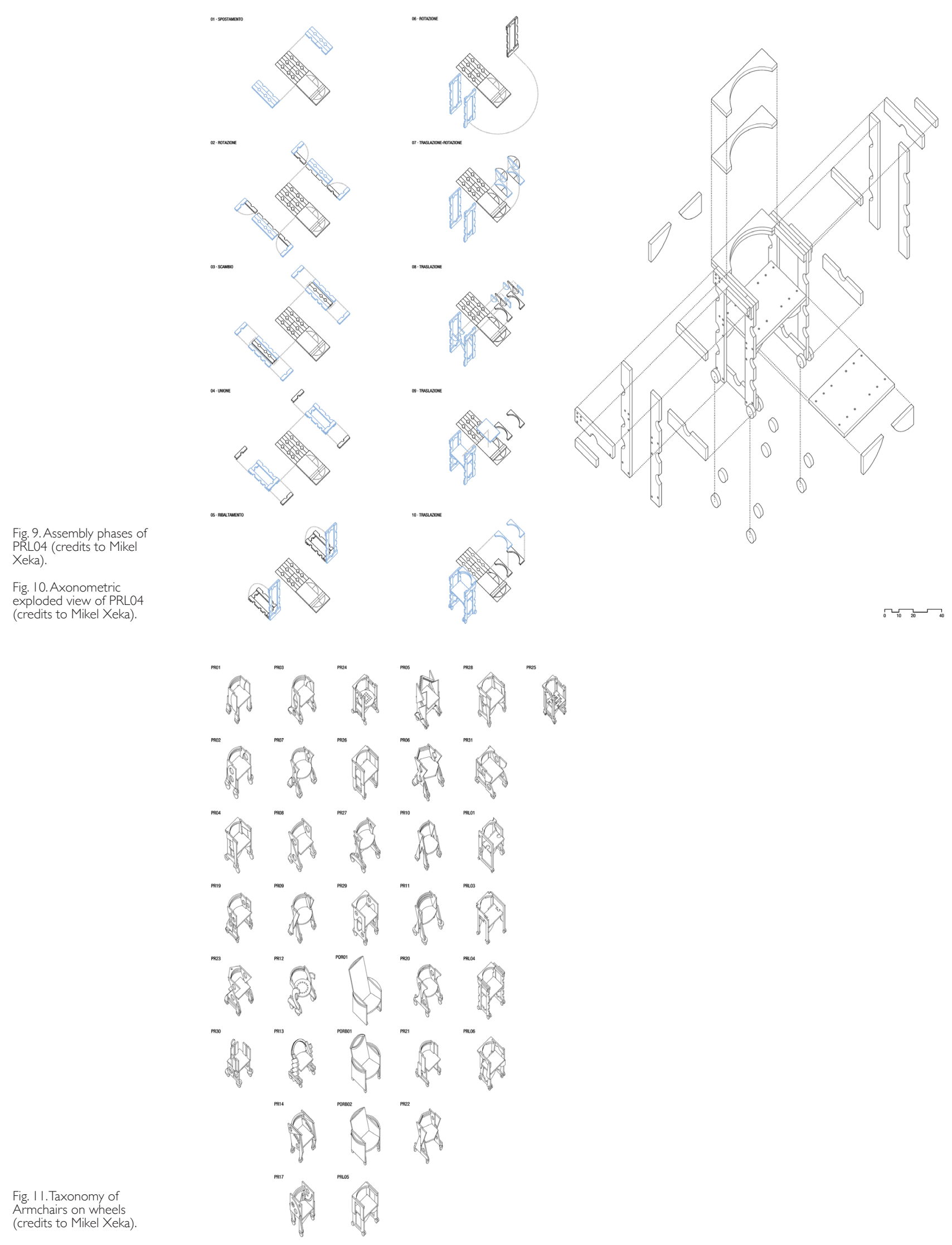




\section{References}

Ambrosi A. (1992). Gli oggetti e le loro rappresentazioni. In A. Ambrosi et al. (a cura di). Geometria e Percezione nei Metodi di Rappresentazione Grafica, pp. 5- 18. Bari: Edipuglia.

Anceschi G. (1992). L'oggetto della raffigurazione. Milano: Etas.

Arnheim R. (2009). Arte e percezione visiva. Milano: Feltrinelli.

Cavani A., Orsini G. (a cura di). (2017). Cesare Leonardi. L'architettura della vita. Barcellona: lazy dog.

Di Napoli G. (2004). Disegnare e Conoscere. La mano, l'occhio, il segno. Milano: Einaudi.

Dorfles G. (2003). Artificio e Natura. Milano: Skira.

Elia M. (2008). VChUTEMAS. Design e avanguardie nella Russia dei Soviet. Milano: Lupetti.

Kepes G. (197I). II linguaggio della visione. Bari: Dedalo.

Klee P. (2009). Teoria della forma e della figurazione. Vol. I: II pensiero Immaginale. Milano: Mimesis.

Leonardi C. (1976). Fotografie 1950// 976. Catalogo della mostra.

Leonardi C., Stagi F. (20 I 8). L'architettura degli Alberi. Barcellona: lazy dog.

Maldonado T. (20।0). Arte e artefatti. Milano: Feltrinelli.

Maldonado T. (20 I5). Disegno industriale: un riesame. Milano: Feltrinelli.

Maldonado T. (20I5). Reale e Virtuale. Milano: Feltrinelli.

Mari E. (2020). 25 modi per piantare un chiodo: Sessant'anni di idee e progetti per difendere un sogno. Milano: Oscar-Mondadori.

Martinelli G. (a cura di). (1994). Cesare Leonardi: Solidi-Solids 1983-1993. Modena: Logos.

Miodini L. (2008). Memoria e Sguardo della scultura. In WunderKammer (a cura di). Cesare Leonardi-Scultura. Catalogo della mostra.

Perec G. (2005). La vita istruzioni per l'uso. Milano: BUR.

Rossi A. (2005). Disegno Design. Natura morta e vita metafisica. Roma: Officina Edizioni.

Sennet R. (2019). L'uomo artigiano. Milano: Feltrinelli.

Ugo V. (199I). I luoghi di Dedalo. Bari: Dedalo.

WunderKammer (a cura di). (2008). Cesare Leonardi-Scultura. Catalogo della mostra.

\section{Author}

Domenico Pastore, Politecnico di Bari, domenico.pastore@poliba.it

To cite this chapter. Pastore Domenico (202I). Dalla superficie al volume. Un'indagine grafica del progetto Solidi di Cesare Leonardis/ From surface to solid. A close reading about Cesare Leonardi's project Solids. In Arena A., Arena M., Mediati D., Raffa P. (a cura di). Connettere. Un disegno per annodare e tessere. Linguagri Distanze Tecnologie. Atti del $42^{\circ}$ Convegno Internazionale dei Docenti delle Discipline della Rappresentazionel Connecting Drawing for weaving relationship. Languages Distances Technologies. Proceedings of the $42^{\text {th }}$ International Conference of Representation Disciplines Teachers. Milano: FrancoAngeli, pp. 945-962 